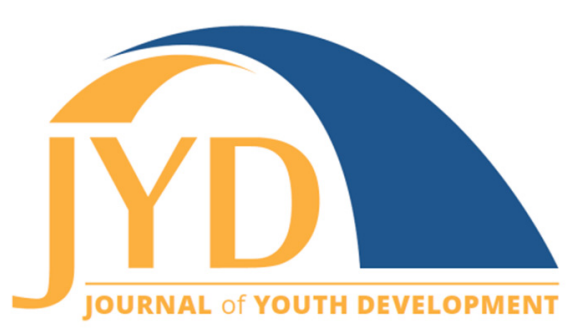

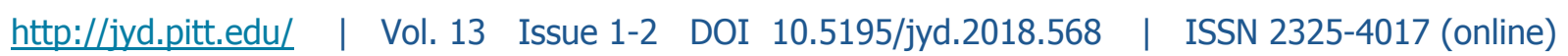

\title{
Teen Staff Perceptions of Their Development in Camp: Insights for Theory and Practice
}

\author{
Marianne Bird \\ University of California Cooperative Extension \\ mbird@ucanr.edu
}

Aarti Subramaniam

University of California Cooperative Extension

asubramaniam@ucdavis.edu

\begin{abstract}
For 15 years, the California 4-H Camping Advisory Committee has studied the experience of campers and teen staff at 4-H camps across the state. The 4-H Youth Development Program has a strong commitment to youth empowerment and embraces a model of youth-adult partnership across all programs. As such, teenagers, with adult support, plan camp programs and serve as staff for younger youth at California 4-H camps. Although program evaluations point to positive experiences for all youth, the high school students who plan and deliver these programs consistently report stronger relationships, greater engagement, and more robust outcomes than campers. In this paper, we review archived qualitative data from two previous California 4-H camp studies to examine, from the perspective of teen camp staff members, the components of the program that may lead to such positive experiences for young teenagers serving in leadership roles. Our findings align with prior research about the benefits of teen leadership at camp, and reinforce that research-based concepts, such as youth-adult partnership and opportunities for meaningful contribution, create an environment that fosters positive development in adolescents.
\end{abstract}

Key words: camp program impact, teen staff development, youth-adult partnership, camp outcomes

\section{Introduction}

Camp programs are noted as contexts where optimum youth development can take place (American Camp Association [ACA], 2005, 2006). When teenagers, only a few years older than the campers themselves, are empowered to plan and deliver camp, they experience enhanced positive youth development outcomes (Bird et al., 2007; Ferrari \& McNeely, 2007).

(cc) EY $_{\text {EY }}$ New articles in this journal are licensed under a Creative Commons Attribution 4.0 License. This journal is published by the University Library System, University of Pittsburgh and is cosponsored by the University of Pittsburgh Press. The Journal of Youth Development is the official peer-reviewed publication of the National Association of Extension 4-H Agents and the National AfterSchool Association. 
Teen Staff Perceptions of Development in Camp

The California 4-H Youth Development Program (CA 4-H YDP), as is true in 4-H across the country, uses a youth-adult partnership model where teenagers work with adults in programming. In 4-H camps, high school students serve as staff and are empowered to lead with support from their adult partners. Research shows that these adolescents score consistently higher than campers in quantitative measures across most outcomes (Bird \& Borba, 2014; Bird et al., 2007; Bird \& Subramaniam, 2008; Lewis, Bird, Borba, Nathaniel \& Schoenfelder, 2017). Data also indicate that teen staff members report a greater sense of involvement, skill development, and supportive relationships than campers. This finding raises the question: what are the key program elements or practices leading to this enhanced teen experience?

Youth-adult partnerships are integral to 4-H and represent one of the core values of the program (Zeldin, Petrokubi \& MacNeil, 2007). Youth-adult partnership takes place when youth and adults plan, learn, and work together, with both groups sharing equally in the decisionmaking process. Together youth and adults achieve better results than either would if working alone (Jones, 2006; Zeldin et al., 2007). The focus in youth-adult partnership is not on developing youth, but on bringing youth into the development of ideas and programs and problem-solving for the betterment of the community (Lofquist, 1989; Zeldin, Christens, \& Powers, 2013).

The researchers were interested in understanding what optimal growth looks like for adolescents at camp, and what should be present in camp settings to promote growth. Research tells us that teens should have experiences that strengthen their competence, confidence, connection, caring, character, and contribution (Lerner et al., 2011; Lerner, Lerner, \& Tufts University Institute for Applied Research in Youth Development, 2013). We know, too, that environments that nurture positive youth development have caring adults, offer opportunities for skill building and decision making, and provide a vehicle for youth to feel they make a difference (Connell \& Gambone, 2002; Eccles \& Gootman, 2002; Gambone, 2006). Research also tells us that youth-adult partnership-where youth and adults work mutually towards a common goal-is an effective means for fostering positive youth development (Benson, Scales, Hamilton, \& Sesma, 2006; Ramey, Lawford, \& Vachon, 2017; Zeldin et al., 2007).

This paper adds to the growing body of research on how camp can be an optimum environment for adolescent growth and development. It examines the camp staff experience from the teen perspective and investigates how elements found in camps may promote adolescent 
Teen Staff Perceptions of Development in Camp

development. Exploring what teens say about their growth will lead to greater understanding of what is actually happening in the 4-H camp experience, and inform how these learnings can be applied broadly in the field of adolescent youth development.

\section{The California 4-H Camping Program}

4-H is the nation's largest youth development program, administered through the land-grant university in each state. California 4-H hosts approximately 20 resident camps, each 5 to 7 days long, which are locally administered by volunteers at leased facilities. Professional staff oversee the volunteers and may or may not be involved in the direct delivery of program. Though the 4-H YDP serves youth 5 to 18 years old, most resident camps limit participation to 9 years old or older. 4-H camps are open to any youth in the community, however the majority of young people who attend have been members of a 4-H club. About 3,500 youth attend CA 4-H camps annually.

In the winter or early spring, high school-aged youth apply, are interviewed, and are selected for camp staff positions. Positions vary in their requirements and degree of responsibility, from assistant living group leaders to youth directors. Teens lead the camp program, from activities and camper living groups to mealtime announcements and staff meetings. Most of these youth attended camp as campers.

Teen staff spend five to seven months, with adult support, planning the camp program. This planning process may include monthly meetings, day-long trainings, and sometimes weekend retreats. A small team of adults select the staff and work closely with the youth directors as they plan these sessions together. These adults also oversee administrative logistics like facility rentals, budget, and risk management. Additional adult chaperones supervise the program at camp and are always present with the teen staff and campers.

\section{Prior Research on Teen Staff Experience and Outcomes at Camp}

A growing body of research has focused on how camp is a positive youth development context for the teens involved in camp leadership. This research indicates that significant benefits exist for teens who lead camps, including increased leadership skills, sense of responsibility, connection with campers, and a sense of community contribution (Bird \& Borba, 2014; Bird \& Subramaniam, 2011; Brandt \& Arnold, 2006; Garst \& Johnson, 2005; Nicholson \& Klem, 2016; 
Teen Staff Perceptions of Development in Camp

Tessman, Duda, \& Pracht, 2012). In addition, researchers have shared how camp experiences translate to workforce and career preparedness for teens (Digby \& Ferrari, 2007).

The California 4-H Camping Advisory Committee has studied camper and teen staff outcomes for the past 15 years. The findings mirror much of what has been found in other states with some variations. Based on the Community Action Framework (Gambone, 2006), in 2005/2006 the committee conducted a 2-year study on camper and teen staff experiences of supports (such as relationships and safety) and opportunities (such as leadership and skill building) at camp (Bird, et al., 2007). The study included a survey, as well as site observations and interviews with teens and adults. Data confirmed that all camps operated with a philosophy of youth-adult partnerships. Results indicated that while both campers and teen staff had positive experiences, teen staff perceived greater supports and opportunities than campers.

Interestingly, when teen campers were compared to teen staff, the staff still scored significantly higher, indicating that the difference was not about age but about the role that teen staff members shared in leading camp (Bird et al., 2007).

A second study in 2013/2014 investigated youth outcomes using the American Camp Association's (ACA) Youth Outcomes Battery (YOB) (ACA, 2009) and focus group interviews. For both years, camper and teen data once again showed that teen staff gained more through their experience than campers. The research team measured four outcomes: responsibility, interest in exploration, teamwork, and affinity for nature. Notably, affinity for nature was the only outcome where no significant difference in staff and campers scores was found (Bird et al., 2014). The evidence seems consistent that although camp itself is a positive youth development context for all youth, the role of leading camp leads to higher outcomes for the young people who are ready to serve rather than to merely receive.

The research team conducted a third study in 2016, utilizing the ACA YOB augmented with open-ended questions. When asked how they felt they had changed as a result of being a camp staff member, the 172 teens participating in the study wrote about a variety of things including communication, teamwork, patience, and connection. Topping the list were responses coded as confidence $(n=35)$, responsibility $(n=26)$, and leadership $(n=24)$. Teen staff also responded to a survey assessing key indicators of youth-adult partnerships and components of training that they received. A majority of the teens responded that they had experienced a "successful youth adult partnership" and that there were "dedicated adults who supported them as teen staff" (Lewis, Bird, Borba, Nathaniel, \& Schoenfelder, 2017). Authors discussed the implications 
Teen Staff Perceptions of Development in Camp

of their findings, suggesting that the teens experienced positive partnerships with adults and felt prepared for their staff role with adults supporting them.

Clearly, patterns exist in the literature, both in the California 4-H studies and those conducted in other states: Teen staff gain consistent positive outcomes through participating in leadership roles, and these outcomes occur in a context of a positive experience, especially successful relationships with adults. However, there is a need for a more nuanced understanding of these outcomes and experiences from the perspective of the teens. Why is camp a place where teens experience this type of growth? What do young people emphasize when they talk of their engagement with this space and the people in it, and what are the implications for promising practice?

\section{Methods}

Our study draws from archival data (interviews and observations) from research conducted in 2005/2006 and 2013/2014 that measured impacts of the California 4-H camp program. While an eight-year gap exists between these two sets of interviews, researchers found the camp program, structure, and youth involvement to be consistent over time, thus allowing for combining data to produce a richer data set. To ensure that the two data sources were comparable enough to use together, researchers chose to compile only selected interview questions that were comparable in meaning and word choice across the two focus groups.

The first study (2005/2006) was an inquiry into how 4-H campers and teen staff experienced youth development supports and opportunities at camp from a sample of four 4-H camps in the state (Bird et al., 2007). The second study (2013/2014) investigated camper and teen staff outcomes in 4-H camp (Bird et al., 2014). The six 4-H camps in this review are a representative sample of 4-H camps in California in their overall philosophy, structure, and operation. All six camps were geographically positioned in different parts of the state. Profiles of the camps are summarized in Table 1.

\section{Participants}

A sample of 38 teen staff (ages 14-18) from four 4-H resident camps in 2006 and two 4-H resident camps in 2014 informed this study. All the teens were in high school (15 years old and above) and were predominantly white, reflecting the demographic of the traditional 4-H club programs in their county at the time the studies took place. 
Journal of Youth Development | http://jyd.pitt.edu/ | Vol. 13 Issue 1-2 DOI 10.5195/jyd.2018.568

Teen Staff Perceptions of Development in Camp

Table 1. Profiles of Camps Involved in California 4-H 2005/2006 and 2013/2014 Studies

\begin{tabular}{|c|c|c|c|c|c|c|c|}
\hline \multirow[t]{2}{*}{ Camp } & \multirow[t]{2}{*}{ Location } & \multirow{2}{*}{$\begin{array}{l}\text { Program } \\
\text { Structure }\end{array}$} & \multirow{2}{*}{$\begin{array}{l}\text { Length } \\
\text { of } \\
\text { session }\end{array}$} & \multicolumn{4}{|c|}{ Number of } \\
\hline & & & & campers & $\begin{array}{l}\text { teen } \\
\text { staff }\end{array}$ & adults & $\begin{array}{l}\text { teens in } \\
\text { interview }\end{array}$ \\
\hline \multicolumn{8}{|c|}{ Camps in 2005/2006 Study } \\
\hline A & $\begin{array}{l}\text { San Bernardino National } \\
\text { Forest, southern CA }\end{array}$ & $\begin{array}{l}\text { Moderately } \\
\text { structured }\end{array}$ & 7 days & 68 & 26 & 12 & 9 \\
\hline B & $\begin{array}{l}\text { Napa mountains, north } \\
\text { bay area, CA }\end{array}$ & $\begin{array}{l}\text { Highly } \\
\text { structured }\end{array}$ & 6 days & 95 & 36 & 21 & 6 \\
\hline $\mathrm{C}$ & $\begin{array}{l}\text { High sierras, northern } \\
\text { CA }\end{array}$ & $\begin{array}{l}\text { Mostly } \\
\text { unstructured }\end{array}$ & 5 days & 140 & 28 & 20 & 7 \\
\hline $\mathrm{D}$ & $\begin{array}{l}\text { Lassen National Forest, } \\
\text { northern CA }\end{array}$ & $\begin{array}{l}\text { Highly } \\
\text { structured }\end{array}$ & 6 days & 88 & 17 & 15 & 5 \\
\hline \multicolumn{8}{|c|}{ Camps in $2013 / 2014$ Study } \\
\hline$E$ & $\begin{array}{l}\text { Stanislaus National } \\
\text { Forest, central sierras, } \\
\text { CA }\end{array}$ & $\begin{array}{l}\text { Moderately } \\
\text { structured }\end{array}$ & 5 days & 117 & 22 & 14 & 5 \\
\hline $\mathrm{F}$ & $\begin{array}{l}\text { Napa mountains, north } \\
\text { bay area, CA }\end{array}$ & $\begin{array}{l}\text { Highly } \\
\text { structured }\end{array}$ & 6 days & 98 & 35 & 33 & 6 \\
\hline
\end{tabular}

\section{Data Sources}

The data for this study included focus group interviews (Vaughn, Schumm, \& Sinagub, 1996) and site observations (four of the six camps).

\section{Focus Groups}

Members of the research teams were trained and worked in pairs to moderate teen focus groups on the second-to-the-last day at each camp. Groups were held without adult leaders present so that teens felt free to state their experiences, and they were assured that their anonymity would be preserved. Moderators worked with a prescribed set of questions and 
Teen Staff Perceptions of Development in Camp

probed responses for greater detail. Interviews averaged between 30-45 minutes long, were recorded, and transcribed. Teens interviewed provided parent consent for participating in the study prior to attending camp.

In 2006, we asked open-ended questions such as "What is your experience of camp?" and, "What do you think is the purpose of camp?" Other questions explored skills and competencies and other outcomes: "Do you think being a camp leader grows your leadership skills? In what way?" and, "How are decisions made at camp?"

In 2014, focus group interviews investigated outcomes contained in the ACA YOB (ACA, 2009), such as responsibility and teamwork. Some comparable questions included, "Have you changed as a result of your experience as camp staff?" and, "Describe your relationship with the adults."

\section{Site Observations}

In 2006, site observations were conducted along with the interviews. Working in pairs, members of the research team attended camps for a two-day period, answered a checklist of predetermined questions, and took field notes. Observations were conducted to understand camp structure, programming, and relationship dynamics between camp staff and campers as well as adult staff. The checklist included information about environment/landscape, facilities, program delivery (including activities, characteristics, and philosophy), mealtime, camper groupings, and camper/staff relationships. For the purpose of this study, we examined the site observation sheets to provide context to the teen staff interviews as well as to recollect details about the various camps. Formal observations were not made of the camps in the 2014 study.

\section{Analysis}

In the first phase of analysis, a team of six researchers individually conducted open coding of the interviews to generate codes related to young people's experiences as camp staff. This type of grounded theory (Strauss, 1987) analysis, allows unique meaning systems, concepts and experiences to be identified by the group under study, in this case the teen staff. However, the team was also guided by the research question to highlight concepts that elucidated impacts of participating in camp, i.e. quotes pertaining to teen experiences and outcomes specifically around some type of change that teens perceived as linked with their participation in their role as teen camp staff. Quotes that attributed environmental or relational factors that contributed 
Teen Staff Perceptions of Development in Camp

to the teens' experiences were also coded. In other words, researchers focused not only on what teens experienced, but how or why these experiences came about (Garst, 2010).

Interviews were coded individually and then discussed as a group to generate consensus-based themes as part of the secondary analysis process. Attributes such as prevalence of a theme (number of camps where these themes were identified), as well as prominence or importance of themes (themes that participants talked about in more depth or suggested were important) were captured. Those themes that appeared in four or more camps ( $75 \%$ or more of the sample) were then selected as representative of the teen staff experience overall.

\section{Findings}

In analyzing the data generated through the six teen focus groups, researchers identified prevalent themes. Data were organized into two categories: (a) the outcomes teens identified as a result of being on the camp staff and (b) the supports and opportunities in the camp staff experience that created the environment to nurture growth. Letters at the end of quotes identify the focus group (lettered A-F in Table 1) from which the comments came.

\section{Outcomes: How Teens Say They Have Grown}

Data from the teen focus groups provided insight into teens' thoughts about their growth through service on the camp staff. The two most salient findings, found throughout all interviews, were the sense of responsibility and the development of life skills that were nurtured through camp participation.

\section{Sense of Responsibility}

In all six interviews, teens expressed a sense of responsibility for the successes of camp and their role as part of the camp team. In all camps, responsibilities included planning and leading all-camp activities or smaller group activities that campers could choose to participate in or rotated through with their living group. All camps also had teens in charge of living groups, usually paired with another teen or an adult. In at least one camp, teens had administrative roles prior to camp, such as marketing or placing campers in cabin groups.

For a portion of the planning meetings you'll meet in your special event group with everyone that's involved in that special event, 
Teen Staff Perceptions of Development in Camp

and you will plan it from start to finish before you even get to camp. $-F$

This year I was very proud because it was almost a week ahead of time and I had everything planned out. $-F$

In all camps, a few teens served as youth directors, creating what was sometimes referred to as "the chain of command," that is, adult staff overseeing youth administrators who oversee youth line staff. Youth directors were selected earlier in the program year, before other staff, and worked closely with adult camp leadership in administrative duties. In five of the six camps, youth directors led staff at the camp planning meetings.

I went from committee member to youth director and I never knew how much effort and time went into [that job] behind the scenes. $-D$

As Top Staff, we make the decisions for almost everything. $-F$

Teens expressed a strong connection with, and responsibility for, campers. This responsibility included their physical care, emotional care, and enjoyment of the program. Teens reflected on their own experience as campers looking up to teenage staff and recognized themselves as role models.

You have to take on responsibility for your kids...make sure they eat, make sure they have good hygiene, you try to help them sleep, all that. $-E$

I know some of them get really homesick. So you sit down with them and tell them stories and they think of you as [a] brother or sister. $-D$

I think we want the campers to have the experience we had, so that would make them want to keep coming back...just like we did. $-F$ 
Journal of Youth Development | http://jyd.pitt.edu/ | Vol. 13 Issue 1-2 DOI 10.5195/jyd.2018.568

Teen Staff Perceptions of Development in Camp

Several teens reported that their relationship with campers was a significant and rewarding part of the camp staff experience. They cited feeling trusted and looked up to when talking about campers.

There's this girl who's a house away from me [back home], and she knows me now, and we've just become really close. $-D$

... you get the feeling that they can trust you. You just feel so important that you just gave this child the comfortableness to come out and tell you [something personal]. $-A$

\section{Opportunities for Skill Development}

Teens in all focus groups mentioned ways in which working on the camp staff had nurtured life skills. Several mentioned being more organized or responsible, more outgoing, and better at public speaking. Youth often spoke about the ability to work with others, an indication of the teamwork required in the camp setting.

I've learned not to push everything back to the last minute-plan ahead. $-E$

It's helped me become a more outgoing person. I was really shy and got so many friends that it was easier for me to talk, like in front of my school to make speeches. $-C$

One of the greater things I learned is recognizing the talents in other people working with you and being able to delegate jobs to them. Being able to respect what other people do to help you and realizing that you are not "The One." $-A$

My listening skills-I think the most important quality of a leader is a person who listens. $-A$

In four of the six interviews, teens also articulated how the skills they acquired applied beyond their camp role and into life. Those skills included teamwork, organization skills, and working 
Teen Staff Perceptions of Development in Camp

with people who are different from themselves. For one teen, this recognition included confirmation of her career choice.

Being a counselor, I've learned a lot about organization and I take that home with me...it's something you can apply to everyday life. $-A$

[Working with staff] has helped me, like in a job in a way; [they're] like co-workers. $-B$

I want to do elementary teaching and doing this has really . . . made it straight that that's what I want to do. I want to deal with young kids and lead them and help them grow. $-E$

\section{Supports and Opportunities: How Teens Felt About Their Experience}

In examining the environment that supported teen outcomes-that is, what elements of the camp staff experience contributed to teen growth-researchers identified three elements: (a) roles and decision making, (b) positive and mutual relationships with adults, and (c) empowerment and contribution. All elements were present in each camp.

\section{Roles and Decision Making}

Youth emphasized that they were both in charge of the delivery of camp program and its planning. Planning examples included deciding learning goals for the campers, the theme, and the program components.

Observations confirmed a high degree of youth leadership in five of the six sites including leading activities, interacting with camper living groups, moderating the campfire, and conducting staff meetings. However, at one site observations revealed that adults were as likely to lead activities as teens, and in some instances, teens were not found at the activity at all. Still, teens interviewed there reported being in charge of the program. In most camps, teens selected the camp activities and also had a choice as to which activities they would plan and lead. They described a cooperative environment during planning meetings in preparation for camp. 
Teen Staff Perceptions of Development in Camp

Through all the camp meetings the committees get together and decide what kind of activities they want to do, like for crafts they decide which craft and on what days and we schedule so we knew what we are doing. $-D$

At the meetings a lot of brainstorming takes places. Everyone throws out all their ideas. For the camp theme we had a whole list of ideas and we just went through and kept voting until we got down to the one that everyone agreed upon. So it's a pool of everyone's thoughts and ideas that helps make the camp go. $-A$

Adult roles at camp tended to fall into two categories: (a) a smaller core who worked with the teens throughout the year in the planning of camp and (b) a larger group of chaperones who may have attended training, but were primarily at camp to assure adult supervision.

[The adults] make less [decisions]. I don't think it's kids rule the camp, it's not like that, but I think a part of it also us, as younger leaders, can relate better to the campers and we would know what would make their experience better. $-F$

I think the authority system works really well. How the adults oversee everything, but at the same time they let us, the junior counselors, have the freedom of planning the entire camp. They let us bring out our creative side. $-A$

Youth recognized adults as having support roles at camp; that is, they provided teens assistance and guidance when needed. Teens also recognized that adults were the ultimate authority.

I think the adults at this camp realize that we do have the ability to do something and they're going to trust us with it, but they also know when they need to step in. $-A$

Even though we make decisions, we always have to run them by [the adults] just to make sure that it's okay, that it's appropriate, and that what we're doing isn't too far-fetched. $-E$ 


\section{Positive and Mutual Relationships with Adults}

In all interviews, teens reported positive relationships with the adults with whom they worked. Teens characterized adults as helpful, both in tasks that needed to be done and in problem solving.

You can go to them with any problem, and they will help you out. $-D$

They're there to help us out if we have kitchen clean up or we need something done. $-E$

Teens spoke of mutuality with adults; they felt no more or less important. The relationship was characterized by mutual respect. In some cases, teens seemed to have an especially close tie with adult administrators.

It's almost like you're on the same level with them. That's how the relationship ends up being. You call them by their first name. And you can make jokes with them. They treat you like you're an equal. $-C$

[The relationship with adults] is very even. They don't think they're above us or anything because they're older...and honestly I can say with a couple of the adults I'm best friends with them. $-F$

\section{Feelings of Empowerment and Contribution}

A theme of self-efficacy ran through the interviews. Teens expressed a sense of authority and, in some cases, confidence, that they were able to do their jobs.

You feel like-not like you have more power-just that people will actually listen to you. You have confidence in yourself that people will listen to you. $-C$ 
Journal of Youth Development | http://jyd.pitt.edu/ | Vol. 13 Issue 1-2 DOI 10.5195/jyd.2018.568

Teen Staff Perceptions of Development in Camp

Wow, I'm really going to affect these children's lives. Am I walking

a straight path? Am I really making good decisions for myself that

they can look up me and say, 'You [know] what, I want to be like

him.' It really makes you take a retrospect and take things back

and to grow. $-A$

Throughout the interviews, teens expressed that they felt they were making a difference. They clearly articulated goals they had for themselves and for campers. They spoke of hard work and the payoff of seeing the end-product of their effort.

The main reason it makes me come to camp, you really make a

difference in people's lives. You can see kids grow. You are

touching their lives. $-A$

\section{Discussion}

We discuss our findings with respect to our enhanced understanding of the teen experience. Additionally, we describe theoretical foundations and implications for practice of camp as a setting for adolescent development.

\section{Better Understanding of the Teen Experience}

What teens reported about their camp experience supported findings from earlier studies about teen leaders at 4-H camp. Data indicated that teens understood their responsibilities and the importance and consequences of their roles (Ferrari \& Risch, 2013; Garst \& Johnson, 2005). Furthermore, our findings revealed they felt they had grown in responsibility and how they defined that growth: following through with planning and commitments, caring for campers, and doing their job as part of the team. Camp structures allowed for progressively more complex leadership roles and responsibility as youth grew in their competency (Tessman et al., 2012).

Teens described skills they developed including organization, communication, public speaking, teamwork, and working with children, many that align with previous research (Digby \& Ferrari, 2007; Garst \& Johnson, 2005). Without prompting, some articulated how these skills transferred from camp to other settings. In their interviews with teen staff who are now adults, Digby and Ferrari (2007) also noted that alumni described transferring skills from camp to the classroom, 
Teen Staff Perceptions of Development in Camp

workplace and community. Perhaps because they applied and interviewed for their positions, teens recognized they were performing a job and treated their responsibilities as such. (For more on the benefits and strategies for connecting teen camp counseling to workforce success, see Ferrari and Arnett, 2011.)

Teens saw themselves as resources and a critical component to make camp happen, a defining characteristic of youth-adult partnership (National Commission on Resources for Youth, 1974; Zelden et al., 2007). Teens spoke of supportive adult relationships, felt a sense of mutual respect, and shared equally in the decision-making process, which is another partnership indicator (Camino, 2000; Jones, 2006; Wood, Larson, \& Brown, 2009). Youth and adult roles varied, but teens consistently expressed feeling valued and trusted.

\section{Adolescent Development in the Context of Camp: Theoretical Implications}

When examining the data in the context of the Five Cs of Positive Youth Development framework (Lerner, 2007), camps appear to provide a prime setting for adolescent development. Teens spoke of growing in competence (listening, organization and teamwork skills), confidence (feeling important, becoming more outgoing) and connection (with campers, adult partners, and the camp community in general). They emphasized caring for younger youth and about doing their job well. In developing character, teens described feeling responsible for the success of the program and well-being of campers, and being committed to filling program expectations.

\section{Contribution}

Contribution-the opportunity to give of oneself in a meaningful way-is important to adolescent development (Eccles \& Gootman, 2002; Lerner, 2007). Also called support for efficacy and mattering, environments that provide this opportunity are youth-based and support autonomy, grant youth responsibility and meaningful challenge, and provide opportunities for making a real difference in the community (Eccles \& Gootman, 2002). Data suggest that California 4-H camps provide this sense of contribution for teen staff.

Our data also suggest that the camp environment provides the supports and opportunities that foster positive youth development (Gambone \& Connell, 2004). Teens reported caring relationships, opportunities for skill building and decision making. Further, our findings suggest that youth-adult partnership plays a critical role to the above happening at camp. 


\section{Implications for Program Design}

Our findings suggest that the following program elements promote adolescent development at camp.

\section{Autonomy and Independence}

The camp environment may encourage teens to share ideas, create plans, and assume responsibility. From problem-solving how to help a homesick camper to planning and leading the evening campfire, teens are granted a great deal of independence, with adults providing appropriate support when needed. Teens have authority and assume genuine leadership roles.

\section{Youth and Adults Share a Focus on Building the Program Together}

Teens experience a unique relationship with adults at 4-H camp. Most adults with whom teens have meaningful relationships sit in positions of authority, often as teachers, coaches, or parents. By virtue of the relationship, teens are the focus of development, and young people are usually not empowered to be active participants in decisions or assume authentic leadership roles.

The youth-adult partnership model is decidedly different. During the planning months prior to camp, teen and adult staff have different (and defined) roles, but the same goal. The focus is not on developing the teens, but rather forming the week-long program for campers. This is not to say that teens don't learn or that adults don't coach or counsel, but to highlight that a shared project brings youth and adults to work together. Teens are recognized as resources in constructing and delivering the camp program. When adults treat teens as capable partners, teens feel valued.

\section{A Tangible Product}

One might see camp as the ultimate service-learning project: the project is well-defined; youth create and carry out an action plan to effect change; and teens can see, and reflect upon, the outcome and their effort. Satisfaction is found in the completed task. This experience builds competence and a deeper understanding of self. 


\section{Meaningful Relationships}

Campers look up to teenagers, creating feelings of importance and specialness for older youth. Teens recall what it was like when they were campers and looked up to teen leaders, so take the responsibility of role modeling seriously. Teens also experience support and care from adults. Cross-age friendships develop. Adolescence is a time of expanding relationships, and camp provides rich opportunities for exploring new connections and developing friendships.

\section{Authentic Contribution}

Evidence suggests teenage staff feel ownership of their camps and the experience they provide to campers. In listening to interviews, one hears a sense of pride as teens speak about their work, their responsibilities, and their relationships with campers. They feel they make a difference for others, and a sense of meaningfulness exists.

\section{Study Limitations and Future Directions}

The data set that informs this paper is narrow, drawn from six focus groups in the California 4-H camp program. Though geographically dispersed, the camps are fairly homogeneous in terms of their demographics, structure, and values, all situated in the traditional 4-H club program. How do adolescents from various populations and differing backgrounds experience camp leadership? Would they describe similar benefits? Which elements in the camp environment best support their growth?

Our study did not include interviews with adolescents at camp who were not on the camp staff. As mentioned, this group of teens in CA 4-H camps is very small, and quantitative data in earlier studies indicated their experience of supports and opportunities at camp does not align with teens on staff. Further study to understand the experience of teen campers, and their similarities and differences with teen camp staff, is needed to better inform how the role of planning and leading camp impacts adolescent outcomes.

\section{Conclusion}

Our findings build on previous studies that document how camp can be an optimum youth development space for teenagers. Findings confirmed that teenagers perceived personal growth, especially in the areas of responsibility and skill building. Some factors that nurtured growth included: genuine decision-making and authority; close, mutual relationships with 
Teen Staff Perceptions of Development in Camp

adults; and feelings of mattering. Youth-adult partnership-that is, teens recognized as a valuable resource-and meaningful roles contributed to feeling valued and to the sense of selfefficacy teens reported. Our findings suggest that the theory and practice of optimum adolescent development at camp should incorporate not only the elements of positive youth development but also mutuality in relationships and roles that allow for a meaningful partnership between youth and adults.

\section{Acknowledgements}

The authors wish to thank Kendra Lewis and members of previous Camping Advisory Committee research teams, especially John Borba, whose work contributed to this paper.

\section{References}

American Camp Association. (2005). Directions: Youth development outcomes of the camp experience. Retrieved from https://www.acacamps.org/sites/default/files/resource_library/report-directionsyouth-development-outcomes.pdf

American Camp Association. (2006). Inspirations: Developmental supports and opportunities of youths' experiences at camp. Retrieved from https://www.acacamps.org/sites/default/files/resource_library/Inspirations.pdf

American Camp Association. (2009). Camp Youth Outcomes Battery: Measuring developmental outcomes in youth programs. Retrieved from https://www.acacamps.org/resource-library/research/acayouth-outcomes-battery

Benson, P., Scales, P., Hamilton, S., \& Sesma, A. (2006). Positive youth development: Theory, research, and applications. In Damon, W. \& Lerner, R., Handbook of Child Psychology (Volume 1). New York, NY: John Wiley \& Sons.

Bird, M., \& Borba, J. (2014). The powerful impact of empowering teens in camp program planning and delivery. International Camping Fellowship: 10th International Camping Congress Research Forum. Retrieved from http://www.campingfellowship.org/upload/file/the-powerful-impact-ofempowering-teens-in-camp-program-planning-and-delivery.pdf

Bird, M., Borba, J., Brenner, J., Brosnahan, A., Coutellier, C., George, J., Kong, L., Schmitt-McQuitty, L., Subramaniam, A., \& Thomas, J., (2007). Beyond evaluation: Findings from the California 4-H camp study. Davis, CA: University of California 4-H Youth Development Program. Retrieved from http://4h.ucanr.edu/files/4427.pdf 
Journal of Youth Development | http://jyd.pitt.edu/ | Vol. 13 Issue 1-2 DOI 10.5195/jyd.2018.568

Teen Staff Perceptions of Development in Camp

Bird, M., Borba, J., Nathanial, K., Portillo, M., Boyes, R., \& Dogan, S. (2014). Lessons learned in utilizing ACA's Youth Outcomes Battery for program improvement. 201 American Camp Association National Research Forum Abstracts, 10-12. Retrieved from https://www.acacamps.org/sites/default/files/resource_library/2014-National-Research-ForumBook-Abstracts.pdf

Bird, M., \& Subramaniam, A. (2008). The impact of empowering teens in camp program delivery. International Camping Fellowship: presentation at the 8th International Camping Congress Research Forum, Quebec, Canada.

Bird, M., \& Subramaniam, A. (2011). Teens as teachers enhance environmental education and personal skills through service learning. Youth Development Research and Evaluation from the University of California Cooperative Extension 2001-2010, 32-29. Retrieved from http://4h.ucanr.edu/files/130750.pdf

Brandt, J., \& Arnold, M. E. (2006). Looking back, the impact of the 4-H camp counselor experience on youth development: A survey of counselor alumni. Journal of Extension, 44(6). Retrieved from www.joe.org/joe/2006december/rb1.php

Camino, L. (2000). Youth-adult partnerships: Entering new territory in community work and research. Applied Developmental Science, 4(1), 11-20.

Connell, J. P., \& Gambone, M. A. (2002). Youth development in community settings: A community action framework. Philadelphia, PA: Youth Development Strategies Inc.

Digby, J. K., \& Ferrari, T. M. (2007). Camp counseling and the development and transfer of workforce skills: The perspective of Ohio 4-H camp counselor alumni. Journal of Youth Development, 2(2). Retrieved from https://nae4a.memberclicks.net/assets/documents/JYD_070202final.pdf

Eccles, J., \& Gootman, J. A. (Eds.) (2002). Community programs to promote youth development. Washington, DC: National Academies Press.

Ferrari, T. M., \& Arnett, N. (2011). Implementing a work-based learning approach to 4-H camp counseling. Journal of Youth Development, 6(4), Article 110604FA001. Retrieved from http://jyd.pitt.edu/ojs/jyd/article/view/161

Ferrari, T. M., \& McNeely, N. N. (2007). Positive youth development: What's camp counseling got to do with it? Findings from a study of Ohio 4-H camp counselors. Journal of Extension, 45(2). Retrieved from http://www.joe.org/joe/2007april/rb7.php

Ferrari, T. M. \& Risch, T. (2013). Exploring 4-H camp counseling as a context for developing responsibility. 2013 American Camp Association Research Forum Abstracts, 19-21. Retrieved from https://www.acacamps.org/sites/default/files/resource library/2013-National-Research-ForumBook-Abstracts.pdf 
Journal of Youth Development | http://jyd.pitt.edu/ | Vol. 13 Issue 1-2 DOI 10.5195/jyd.2018.568

Teen Staff Perceptions of Development in Camp

Gambone, M. A. (2006). Community action and youth development: What can be done and how can we measure progress? In K. Fulbright-Anderson \& P. Auspos (Eds.). Community change: Theories, practice, and evidence. Washington, DC: The Aspen Institute.

Gambone, M. A., \& Connell, J. P. (2004). The community action framework for youth development. The Prevention Researcher, 11(2), 17-20.

Garst, B. A. (2010). From what to how: Targeting specific factors that influence outcomes. Journal of Extension, 48(6). https://joe.org/joe/2010december/pdf/JOE_v48_6comm1.pdf

Garst, B., \& Johnson, J. (2005). Adolescent leadership skill development through residential 4-H camp counseling. Journal of Extension, 43(5). Retrieved from http://www.joe.org/joe/2005october/rb5.shtml

Jones, K. R. (2006). Relationships matter: A mixed-methods evaluation of youth and adults working together as partners. Journal of Youth Development, 1(2), 33-46. Retrieved from http://jyd.pitt.edu/ojs/jyd/article/view/384

Lerner, R. M. (2007). The good teen: Rescuing adolescence from the myths of the storm and stress years. New York, NY: Stonesong Press.

Lerner, R. M., Lerner, J. V., Lewin-Bizan, S., Bowers, E. P., Boyd, M. J., Mueller, M. K., . . Napolitano, C. M., (2011). Positive youth development: Process, programs, and problematics. Journal of Youth Development, 6(3), 41-64. Retrieved from https://jyd.pitt.edu/ojs/jyd/article/download/174/160\&hl=en\&sa=X\&scisig=AAGBfm2PGuAvhnfJje OPHVQLW_N2vvuCbw\&nossI $=1 \&$ oi=scholarr

Lerner, R. M., Lerner, J. V., \& Tufts University Institute for Applied Research in Youth Development. (2013). The positive development of youth: Comprehensive findings from the 4-H study of positive youth development. Chevy Chase, MD: National 4-H Council. Retrieved from http://www.4-h.org/about/youth-development-research/ https://4-h.org/wpcontent/uploads/2016/02/4-H-Study-of-Positive-Youth-Development-Full-Report.pdf

Lewis, K., Bird, M., Borba, J., Nathaniel, K., \& Schoenfelder, E. (2017). Teen staff experiences in California 4-H camps. 2017 American Camp Association Research Forum Abstracts, 19-21. Retrieved from http://www.acacamps.org/sites/default/files/resource_library/2017_ACA_Book_of_Abstracts.pdf

Lofquist, W. A. (1989). The spectrum of attitudes: Building a theory of youth development. New Designs for Youth Development, 9, 3-6.

National Commission on Resources for Youth. (1974). New roles for youth in the school and community. New York, NY: Citation.

Nicholson, D. J., \& Klem, M. D. (2016). The value of being a camp counselor: A study of the experiences and personal growth of the Missouri 4-H camp counselors. Camping Magazine. Retrieved from 
Teen Staff Perceptions of Development in Camp

http://www.hfpg.org/files/3214/8553/5933/The_Value_of_Being_a_Camp_Counselor_A_Study_ of_the_Experiences_and_Pers....pdf

Ramey, H. L., Lawford, H. L., \& Vachon, W. (2017). Youth-adult partnership in work with youth: An overview. Journal of Youth Development, 12(4), Retrieved from http://jyd.pitt.edu/ojs/jyd/article/view/171204FA003

Strauss, A. (1987). Qualitative analysis for social scientists. UK: Cambridge University Press.

Tessman, D., Duda, S.L., \& Pracht, D. (2012). Ladders to leadership: What camp counselor positions do for youth. Journal of Youth Development, 73 ). Retrieved from http://jyd.pitt.edu/ojs/jyd/article/view/127

Vaughn, S., Schumm, J., \& Sinagub, J. (1996). Focus group interviews in education and psychology. Thousand Oaks, CA: Sage.

Wood, D., Larson, R. W., \& Brown, J. R. (2009). How adolescents come to see themselves as more responsible through participation in youth programs. Child Development, 80(1), 295-309. Retrieved from http://youthdev.illinois.edu/wp-content/uploads/2013/10/Wood-Larson-Brown2009-How-Adolescents-Come-to-See-Themselves.pdf

Zeldin, S., Christens, B. D., \& Powers, J. L. (2013). The psychology and practice of youth-adult partnership: Bridging generations for youth development and community change. American Journal of Community Psychology, 51, 385-397.

Zeldin, S., Petrokubi, J., \& MacNeil, C. (2007). Youth adult partnership in community decision making. Chevy Chase, MD: National 4-H Council. Retrieved from http://4h.ucanr.edu/files/2427.pdf 